\title{
Discussion for Applicability of the Fair Value Measurement
}

\section{in the Financial Crisis}

\author{
Yujing Gao \& Gaichune \\ Shandong Economic University, Accounting Institute \\ Jinan 250014, China \\ E-mail: gaoyujing152760@163.com
}

\begin{abstract}
In the context of the whole world financial crisis, the fair value measurement has been provoked furious condemnation. Some even require revert fair value measurement to historical cost valuation method. In this paper, the author analyze the relation between fair value and financial crisis, and on this basis, pointed out that the fair value measurement is only a catalyst rather than the root causes of the financial crisis. Fair value measurement still has applicability in the context of the financial crisis, and analyzed the reasons for the applicability of the fair value.
\end{abstract}

Keywords: Financial Crisis, Fair value, Applicability

\section{Raise the Question}

The U.S. financial crisis triggered by the sub-prime crisis has swept the globe, and evolved into a global financial crisis. At the present time, the financial crisis is engulfing Wall Street crazily, and also hitting violently the fair value measurement which representing the future direction. Although the fair value once bring happiness to the Wall Street bankers, but now they are talking about the mere mention of the fair value. They said that the fair value, particularly in the measurement of market-based approach, can not objectively reflect the value of the assets, and also in the financial crisis, made the company reports too "ugly", affected the company's performance and investors' confidence, played a fueling role. Worse still, some people believe that the international accounting standards' provisions for the fair value are one of the culprits that causing the financial crisis. The sound was immediately received by a number of financial industry and members of Congress. So they combined to pressure the government and require fair value measurement method will be changed back to historical cost method in order to stabilize the people's hearts.

\section{Fair Value Measurements and Financial Crisis}

The U.S. Financial Accounting Standards No. 157 guidelines require that there are three levels about fair value measurement. The first level is the financial products that have an active market transactions, the fair value of such products is determined by an active market price. The second level is the financial products that have not an active trading market circumstances, the fair value of these products refer to the similar products in an active market, or use the value models that can be supported by an objective reference value. The third level is the financial products that have not an active trading market, the fair value of these products require managements establish the valuation models which based on the subjective judgments and the market assumptions (Yang, 2008, p.147).

Before the outbreak of the financial crisis, financial instruments are pricing in accordance with the first level. But financial crisis has led the real market to a no longer active market. In a no longer active market, the financial institutions should valuation the fair value under the third level. However, because the guidelines are not entirely reasonable, so the financial instruments still valuation in accordance with the first-level. And enable the prices of the financial assets and derivative financial products departure from its intrinsic value badly. The assets that measured by fair value are undervalued. A large number of provision for impairment, result in huge losses of book value, thus affect the report performance. The investors analyze operation performance according to the published financial statements data and reinforce people's confidence crisis, but the actual loss should be much smaller than the book. Meanwhile, due to the sluggish market conditions, most of the normal production and business operations have been affected, reducing the scale of operation exist widely, and part of the transaction business are at the edge of bankruptcy, the value of assets or liabilities that held by enterprises departure from the true value.(E,2008, p.74-75) The fair value can not reflect the fair value of the assets, and deeply measure the extent of the financial crisis. So it become the object of criticism, and had been accused of financial crisis "worse" or even the "culprit" of financial crisis. 


\section{Fair Value Measurement is a Catalyst Rather than the Root Causes of the Financial Crisis}

However, the fair value measurement is not the "culprit" of the financial crisis, it only played a catalytic role in the financial crisis. Fair value itself has no problem. The question is that the prerequisite of fair value measurement has changed. In the financial crisis, an active trading market does not exist. Therefore, the fair value of financial products is no longer determined by the market quotations. However, as the changed prerequisite, people still select the fair value. Therefore, fair value measurement methods deep the financial crisis, and led to people's criticism of fair value measurement.

The fair value measurement has the pro-cyclical feature, it can enhance the sense of happiness at bubble period, and escalate panic at the time of crisis (Fu, 2008, p.10-15). In accordance with the market valuation cases, when markets are weak, the financial asset prices fell, each participant in the market will report losses, although this is a nominally loss, but the rights and interests will be eroded. Since the second half of 2007, the U.S. sub-prime mortgage crisis unfold, along with the rising of mortgage default rates, financial products' prices continued to fall, resulting in a large number of financial institutions have to provision for impairment of its assets, resulted in a large number of investors selling the holding financial assets crazily, and a sharp decline in the value of financial assets, financial asset prices fall further, and hit the investor confidence, thus the investor continue to sell financial assets, resulting in a new round of falling of financial asset prices(Chen,2008,p.108-109). It is that the fair value' pro-cyclical feature exacerbate the financial crisis, and form a double vicious circle of the capital markets and commodity markets.

However, the application of fair value measurement is totally clear and definite response to investors' requests and requirements. Fair value provides more transparent information to investors. But the financial industry neglect the investors' information needs, only criticize fair value measurements, but can not raise a convincing alternative. Fair value is more transparent, timely and efficient in making information users understand the scale and impact of financial crisis than historical cost. Fair value measurement is not the root causes of the financial crisis, in fact, the financial sector created the real estate bubble, and through unregulated, non-transparent financial innovations such as asset securitization approach to enlarge the financial asset bubble, since the United States use historical cost principle long-term, these issue has not surfaced, the accounting with fair value measurement model, timely, transparently and openly disclosure the financial asset bubbles, make the shortcomings of the U.S. financial system public in the world, prompting the financial sector, investors and financial regulatory authorities to address and resolve financial asset bubbles. If there is no use of fair value measurement, investors may be concealed in the bubble that the financial sector created.

\section{Fair Value Measurement Still has the Applicability in the Global Financial Crisis}

\subsection{Fair Value Measurement Make Accounting Earnings More Relevant}

According to the traditional concept of accounting earnings, accounting earnings is the differences between the realized income and the corresponding costs. The fair value measurement is to take measure of the fair value of the capital and liabilities at the balance sheet date, but also measured the profits and losses that caused by the change of fair value. This can compensate for the lacking of accounting earnings, and more reasonably reflect the financial position, operating results, cash flow and real earnings of the enterprise (Zhu,2008,p.4-5). The accounting information that measured at fair value provides more highly relevant information compared to historical cost.

\subsection{Fair Value Measurement's Basis for Decision-usefulness View Still Exists}

The basic goal of modern accounting is to be useful for a decision-making, takes into account to reflect the fiduciary duty. In the concept of fiduciary responsibility, the accounting information mainly report the responsibility of management that fulfill the economic situation. Assets measurement is mainly to protect the assets safety and integrity, and more emphasis on the reliability of accounting information, and select historical cost as a measurement model. In the decision-usefulness view, the relevance associated with the concept of decision-useful features. People increase relevance in order to enhance the usefulness of the decision-making. Accounting goal require not only the information in the past, but also the information on the performance of present and future. People advocate using a market-pricing to determine the fair value of financial assets. Fair value measurement is not only able to meet the needs of short-term speculative, but also able to meet the needs of investors in the long-term decision-making, which is widely used (Peng,2008, p.4-8). Currently, fair value measurement's basis for decision-usefulness view still exists. It is difficult to weaken the fair value measurement.

\subsection{The Basic Reason of Fair Value Measurement is Operation Rather than the Basic Usage}

Determining fair value by an active market quotation can reflect the real value of financial assets, in accordance with the economic substance of the fair value, and also operational. However, when a mutation in the market, especially the U.S. financial crisis has led to loss of market confidence, the market quotation is not the optimal choice to determine the fair value. In the financial crisis, the troubled sellers of assets are in the "Bargain" situation and irrational state, market price is also similar to the clearing price of rapid realization assets, does not meet the accounting assumptions of 
"sustainable management". Moreover, in this financial crisis, there appeared the phenomenon of market liquidity suddenly disappeared, and the trading volume of many varieties of stock shrank greatly, indeed, without a buyer, in this case the market is or not an active market is worth exploring. The causes of the financial crisis are the excessive debt of consumers and over-leveraged of financial institutions, excessive securitization of capital markets and excessive liberalization of financial supervision. The accounting standards are not the culprit, fair value measurement's application basis and the economic meaning have no problems, but the method of operation based on the non-fair market price to determine the fair value in practice, fueled some effect to the financial crisis. We should not deny fair value' scientific content, but should establish an effective mechanism to adjust the mode to determine fair value under non-normal, non-efficient market condition.

\subsection{SEC Relax the Fair Value Measurement Standard Rather than Stopping}

September 30, 2008, the United States Securities and Exchange Commission released a guidance of Financial Accounting Standards No. 157 "Fair Value Accounting", requiring companies can not simply rely on the non-active trading price under the financial crisis conditions, but should determine the fair value of financial assets through the length of time of price declines, or as well as the judge of the market liquidity, or with the help of internal valuation models and assumptions. The second rescue package that U.S. House of Representatives through on October 3, specifically granted the United States Securities and Exchange Commission the re-classification rights for the financial assets. And asked the U.S. Securities and Exchange Commission refer the investigation report about the market measurement to congress within 90 days, and decide whether to terminate the accounting standards, but still insist on using fair value measurement before the outcome of the investigation. This shows that the provisions of No. 157 guidelines have been relaxed to some extent, and also reflects that the SEC and the FASB has not completely succumbed to the pressure of the financial sector, resist the pressure of stopping fair value accounting standards completely.

\section{References}

Chen, Yuyuan. Generally. (2008).Accepted Accounting Principles Which Related to The U.S. Sub-prime Mortgage Crisis and The Response. Communication of Finance and Accounting, 10,108-109.

E, zhaodi. (2008). Fair Value and the U.S. Subprime Mortgage Crisis. CO-opertive economy \& Science, 12, 74-75

Fu, Qiang. (2008). Fair Value and Sub-prime. Accounting Research, 11, 10-15.

Peng, Nanting and Wang, Xiwu. (2008). The Fair Value Accounting under the Financial Crisis. Accounting Research, 12, 4-8.

Yang, Guanghui. (2008). Reflections on Fair Value Measurements Triggered by the Financial Crisis. Economic \& Trade, $10,147$.

Zhu, Jinping. (2008). The Trend of The Fair Value. Friends of Accounting, 11, 4-5. 